\title{
Urbanização reflexa: a emergência de arranjos urbanos intermediários no Brasil pós-1990
}

Humberto Miranda. Universidade Estadual de Campinas, Unicamp, São Paulo, Brasil.

Evaldo Gomes-Júnior. Universidade Estadual de Campinas, Unicamp, São Paulo, Brasil.

RESUMO $\mid \mathrm{O}$ artigo discute o papel que as cidades intermediárias cumprem na hierarquia urbana brasileira, visando ao entendimento das novas determinaçóes urbanas e regionais em países subdesenvolvidos. Após os anos de 1990, o modo como se deu a articulação entre o urbano, o rural e o regional alterou o padrão de urbanização brasileiro. Todavia, os investimentos em infraestrutura logística e a os processos técnicos de modernização econômica penetram nos espaços de expansão da fronteira agroexportadora e intensificam o ritmo de urbanização em áreas não metropolitanas, impulsionando a urbanização reflexa.

PALAVRAS-CHAVE | urbanização, cidades intermediárias, reestruturação territorial.

ABSTRACT | This article analyzes the role of intermediate sized cities among the other urban scales in Brazil. These scales modify the urban hierarchies in underdeveloped nations. After the 1990s, the form of coordination between urban, rural and regional changed the pattern of Brazilian urbanization. However, investments in logistics infrastructure and the technical processes of economic modernization, penetrated in the expansion areas of the agro-export frontier and intensified the pace of urbanization in non-metropolitan areas, making way for reflex urbanization.

KEYWORDS | urbanization, intermediate cities, territorial restructuring. 


\section{Introduçáo}

O objetivo deste artigo é discutir o papel que os arranjos urbanos intermediários cumprem nas hierarquias urbanas, visando ao entendimento das novas determinaçóes urbano-regionais impostas pelas transformaçóes em curso em áreas não metropolitanas do Brasil. Isto se justifica porque a perspectiva de integração econômico-territorial do desenvolvimento nacional, pautada na complementaridade intersetorial entre as regióes no período 1950-1980, cedeu lugar à outra com menores nexos de solidariedade inter-regional e fragmentadora dos interesses econômicos nas regióes, pós-1990.

Parte-se de uma pergunta geral: como as transformações impostas pelos capitais que se deslocam para as áreas de fronteiras implicaram em mudanças nas hierarquias urbano-regionais no Brasil? Adiciona-se a essa, questôes específicas como: em que medida o crescimento das cidades intermediárias estaria relacionado a tais mudanças? Qual a importância hierárquica dessas cidades para tornar crível uma integração econômico-territorial mais dinâmica? Que fatores econômicos importam à capacidade de mediaçáo dessas cidades em face de contextos espaciais diferenciados, como o das áreas não metropolitanas?

Entre os anos de 1990 a 2010, observa-se de um lado, os grandes centros urbanos se saturando de gente e atividades e as cidades médias crescendo quantitativamente e ganhando destaque nas regióes metropolitanas brasileiras; de outro, a emergência de pequenas e médias cidades nas áreas de expansão da fronteira agrícola vão modificando as relaçóes interurbanas, por meio do surgimento de novas centralidades urbanas. Consideramos que as pequenas e médias cidades poderiam gerar maior capacidade de mediação não fossem obstáculos estruturais ao desenvolvimento urbano-regional.

A noção de arranjos urbanos intermediários, tratada neste contexto, leva em conta um conjunto (ou volume) de cidades, ditas intermediárias, cuja intensidade da urbanizaçáo -ou seja, situação em que o ritmo do crescimento da população urbana de uma cidade é maior que o ritmo de crescimento de sua população total- passou a ser notada nas áreas não metropolitanas de determinadas regióes brasileiras. São intermediárias, primeiro, porque crescem fora das áreas metropolitanas de urbanizaçáo mais concentrada e, segundo, porque criam maiores vínculos com outras cidades em áreas de urbanização mais dispersa, formando elos dentro e fora da região.

Após o período 1950-1980, a urbanização brasileira torna-se generalizada, consolidando-se nas áreas metropolitanas e intensificando-se nas áreas não metropolitanas nas décadas de 1990, 2000 e 2010. Constata-se na tabela 1 que, após a década de 1980, ocorre uma mudança na distribuição de cidades por tamanho populacional no sistema urbano nacional. Constatamos que o crescimento líquido do número de cidades entre 100 mil e 1 milhão de habitantes foi expressivo no Brasil após 1990, passando de 133 cidades em 1980 para 270, em 2010. 
TABELA I | Brasil: número de municípios por classes da população

\begin{tabular}{|l|r|r|r|r|r|r|r|}
\hline $\begin{array}{c}\text { CLASSES DE } \\
\text { POPULAÇÃo } \\
\text { (HABITANTES) }\end{array}$ & I950 & I960 & I970 & I980 & I99I & 2000 & 20I0 \\
\hline Acima de 5 milhôes & - & - & 1 & 2 & 2 & 2 & 2 \\
\hline Entre 2 e 5 milhóes & 2 & 2 & 1 & - & 2 & 4 & 4 \\
\hline Entre 1 e 2 milhôes & - & - & 3 & 7 & 7 & 6 & 6 \\
\hline Entre 500 mil e 1 milhão & 1 & 5 & 6 & 9 & 14 & 19 & 25 \\
\hline Entre 100 e 500 mil & 35 & 57 & 83 & 124 & 162 & 193 & 245 \\
\hline Até 100 mil & 1.851 & 2.702 & 3.858 & 3.849 & 4.304 & 5.283 & 5.282 \\
\hline Total & 1.889 & 2.766 & 3.952 & 3.991 & 4.488 & 5.507 & 5.564 \\
\hline
\end{tabular}

FONTE IBGE - VÁRIOS CENSOS DEMOGRÁFICOS. ELABORAÇÃo PRÓPRIA

O crescimento do número de cidades situadas na classe entre 100 e 500 mil habitantes e entre 500 mil e 1 (um) milhão de habitantes indicam uma mudança nas hierarquias urbanas. Ou seja, houve um aumento no poder de comando econômico-territorial das metrópoles e os novos comandos surgidos, os arranjos urbanoregionais, conforme discutidos por Moura (2009) e os arranjos urbanos intermediários, aqui discutidos, passaram a se estabelecer em níveis diversos da rede urbana brasileira. O fenômeno já foi chamado de desmetropolização por Santos (2009), significando a repartição da população urbana com outros grandes núcleos. Porém, Jordan e Simioni (1998), num estudo feito para a CEPAL (Comissão Econômica para a América Latina e o Caribe), mostram o efeito generalizado desse fenômeno na América Latina, no período pós-1990.

En todos los países que contaban con la información pertinente, las ciudades de entre 50 mil y 1 millón de habitantes se subdividen en dos categorías: las menores de 500 mil habitantes y las que tenían entre 500 mil y 1 millón de habitantes. Las ciudades de 50 mil a 499999 habitantes han tendido a crecer más rápidamente que las de entre 500 mil y 1 millón de habitantes. Las diferencias son notables en Argentina, Chile y Venezuela; son moderadas en México y Perú y prácticamente no existen en Colombia. La única excepción a esta regularidad es Bolivia... (Jordan \& Simioni, 1998, p. 60).

Dada esta regularidade, buscamos entender o que aconteceu no Brasil. Para isso, construímos uma tipologia (tabela 2), segundo quatro níveis hierárquicos de repartição da população total e o número de municípios de diferentes tamanhos contidos nos mesmos, a fim de mostrar a emergência de novos arranjos urbanos. 
TABELA 2 Tipologia de níveis hierárquicos, por critério populacional

\begin{tabular}{|c|c|}
\hline Superior & $\begin{array}{l}\text { Composto por municípios das principais regiôes metropolitanas do país, com mais } \\
\text { de um milhão de habitantes e que concentram } 37,8 \text { milhôes da populaçáo brasileira } \\
\text { (ou } 21,1 \% \text { da populaçâo total do país) em } 12 \text { cidades. }\end{array}$ \\
\hline $\begin{array}{l}\text { Intermediário } \\
\text { concentrado }\end{array}$ & $\begin{array}{l}\text { Composto por municípios de regiōes metropolitanas, capitais de estados e centros } \\
\text { regionais, com mais de } 100 \text { mil e menos de um milhâo de habitantes e que concen- } \\
\text { tram } 33,7 \% \text { da populaçáo brasileira em } 270 \text { cidades, com importante capacidade de } \\
\text { intermediaçáa. }\end{array}$ \\
\hline Inferior & $\begin{array}{l}\text { Composto por municípios, com exceção daqueles dos níveis anteriores, de até } 100 \\
\text { mil habitantes e que concentram } 45,2 \% \text { da população brasileira em } 95 \%(5.285) \text { do } \\
\text { total de cidades. }\end{array}$ \\
\hline $\begin{array}{l}\text { Intermediário } \\
\text { disperso }\end{array}$ & $\begin{array}{l}\text { Composto por } 325 \text { municípios com população entre } 50 \text { e } 100 \text { mil habitantes, ou } \\
11,7 \% \text { da populaçáo total, que formam um conjunto de cidades intermediárias } \\
\text { contidas no nível hierárquico Inferior, e que ganham importância na rede urbana } \\
\text { para determinadas regióes. }\end{array}$ \\
\hline
\end{tabular}

FONTE CENSO DEMOGRÁFICO DO IBGE (2OIO) - ELABORAÇÃo PRÓPRIA

Apesar dessa tipologia ser muito geral - pois vários dos pequenos e médios municípios estáo orbitando simultaneamente em espaços muito estruturados (regióes metropolitanas) ou pouco estruturados (áreas de expansão da fronteira)-, ela mostra que os níveis intermediários concentrado e disperso caracterizam melhor o sistema urbano brasileiro quanto à distribuição de cidades pelo território nacional e quanto ao sentido da direçáo interurbana do fluxo de pessoas e mercadorias. Consideramos que tais níveis responderam ao avanço nos processos de modernização econômica do território e aceleraram o ritmo de urbanização nas áreas não metropolitanas.

O estudo dos níveis intermediários concentrado e disperso é, assim, fundamental para analisar a emergência de comandos intermediários nas hierarquias urbanoregionais das áreas não metropolitanas do Brasil. $\mathrm{O}$ argumento é que as cidades que compóe esses novos arranjos urbanos adquirem maior ou menor centralidade (posição, tamanho, função, forma e estrutura) devido aos impactos dos investimentos em infraestrutura de transportes e do crescimento do setor de serviços em função das atividades de agroexportação. Perdas ou ganhos de centralidade ocorrem por vários motivos, mas nos interessa considerar a situação em que estas perdas e ganhos se compensam por meio da subdivisão de funções num espaço onde a dispersão dos núcleos urbanos é marcante.

Além desta in trodução, o artigo está subdividido em mais três seções e a conclusão. $\mathrm{Na}$ primeira seção, faz-se uma discussão mais teórico-conceitual sobre o papel das cidades intermediárias na urbanizaçâo reflexa. Na segunda, discute-se a importância dos fatores macroestruturais para a compreensão dos limites enfrentados pelas cidades intermediárias associadas aos arranjos urbanos. Na terceira, abordam-se os investimentos em obras de infraestrutura como fatores condicionantes do avanço da "fronteira urbanizada", o que é ilustrado pelo caso da Fronteira Ampla, situada nas Regióes Centro-Oeste e Norte do Brasil. Nas conclusóes, fazemos uma breve generalização do caso brasileiro para os países latino-americanos. 


\section{Hierarquias urbanas e urbanizaçáo reflexa: uma perspectiva conceitual}

O crescimento da população urbana no Brasil tomado em dois períodos históricos longos, de trinta anos cada, com o primeiro ocorrendo no auge do desenvolvimentismo, de 1950 a 1980 e o segundo, no auge do neoliberalismo, de 1980 a 2010, mostra a importância do nexo urbano-industrial no primeiro e a perda deste no segundo. Conforme ressalta Milton Santos (2008), não é possível mais afirmar que o espaço brasileiro é estruturado somente pelos interesses urbano-industriais. Daí a necessidade de investigar os novos arranjos urbanos e seu papel na mudança das hierarquias urbanas. Pergunta-se: até que ponto as cidades intermediárias são uma boa medida à escala regional do tipo de urbanização que acontece nas áreas de expansão da fronteira agromineral? Se as cidades intermediárias passaram a ter alguma dinâmica social e econômica mais relevante naquelas áreas, como lidar com o alto grau de dispersão da urbanização em determinadas regióes brasileiras?

O propósito desta seção é entender as cidades intermediárias como espaços sujeitos a uma urbanizaçâo reflexa, cuja dinâmica é emanada de fora para dentro das áreas não metropolitanas e influenciada por novas determinaçóes macroestruturais. Dentro dessa perspectiva teórico-conceitual, ainda que de forma preliminar, reunimos aqui alguns autores clássicos do debate regional e urbano brasileiro para destacar três elementos analíticos: a relação entre rede urbana e (re)hierarquização, entre urbanizaçấo da fronteira, concentração fundiária e dispersão das cidades e entre arranjo urbano intermediário e cidades intermediárias.

Quanto à primeira relação, entende-se que o papel das cidades na rede urbana só é discernível quando podemos constatar uma capacidade de inter-mediação da cidade, sendo o entendimento sobre suas articulações interurbanas fundamental. Do ponto de vista convencional, as análises disponíveis sobre rede urbana trataram bem das articulaçóes socioeconômicas no território (Lobato Corrêa, 2006; Instituto de Pesquisa Econômica Aplicada [IPEA], 2001), mas nem tanto do processo de hierarquização, por considerar como dado o privilégio da escala metropolitana. Ainda assim, é importante reter dessa literatura a noção de hierarquia. Lobato Corrêa (2011) cita três condiçóes mínimas para a existência de uma rede urbana: (i) uma economia de mercado desenvolvida, (ii) vários pontos no espaço para realizar as transaçôes econômicas e (ii) uma importante diferenciação hierárquica derivada das duas condiçôes anteriores. Segundo esse autor, "deve haver um mínimo de interaçôes entre esses pontos fixos, interaçôes que refletem e ratificam uma diferenciação hierárquica e/ou em termos de especialização produtiva entre eles" (Lobato Corrêa, 2011, p. 94).

Salienta-se que a noção de hierarquia, como definida acima, é um atributo indispensável para conceituar uma rede urbana. Porém, ao conceituá-la, corre-se o risco de se perder de vista as características dos arranjos urbanos que qualificam o sentido hierárquico adquirido pelas cidades que ganham centralidade. Por isso, interessa-nos mais o movimento de aquisição de centralidades -funçóes e posiçóes das cidadesnas áreas não metropolitanas que, necessariamente, a fixação delas numa rede urbana mais adensada ou cuja importância maior das cidades pequenas e médias se dê pela localização privilegiada numa área metropolitana mais desenvolvida. Esse 
movimento de (re)hierarquização, a nosso ver, é que define o arranjo urbano e não a fixação de cidades (antimovimento) de determinado porte numa rede urbana, supostamente, consolidada.

Fruto dessa discussão, considera-se que: a articulação das cidades na rede urbana é o que lhes permite exercer de forma duradoura uma relação com outras situadas no lugar, na região ou fora dela; o ritmo de crescimento da população das cidades no conjunto do país e nas respectivas regiốes importa para determinar a intensificação dos fluxos de pessoas e mercadorias; e os vetores de investimento produtivo e/ou em infraestrutura podem estar relacionados ao aumento da intermediaçáo de bens e serviços que um determinado conjunto de cidades foi ampliando e não apenas uma cidade individualmente.

Concernente à segunda relação, consideramos oportuna a abordagem de Bertha Becker (2013), que qualifica as cidades que "comandam" a economia como aquelas "capazes de criar trabalho novo". No entendimento da autora, nas áreas não metropolitanas, as cidades associadas a cadeias produtivas completas conseguem superar impasses estruturais nas regióes e tornam-se dinâmicas. Ela mostra, por exemplo, que diferenças no povoamento da região devem ser levadas em conta, pois, se for rarefeita, haverá maiores dificuldades para que as "cidades locais" interajam, mesmo na atual fase de desenvolvimento dos meios técnico-científicos.

Em trabalho anterior, "Fronteira e urbanização repensadas", Becker (1985) aborda a fronteira como espaço não plenamente estruturado para receber e dar funcionalidade às relaçóes capitalistas e nem integrado ao espaço global via urbanização, a fim de atender a distintos interesses sociais e econômicos da modernizaçáo. Nesse sentido, afirma que "a estruturação da fronteira se viabiliza pela mediaçáo do urbano", que serve, segundo a autora, "de base logística para o projeto de sua rápida ocupaçáo" (p. 355). Chama a atenção para o fato de que, no passado, foram necessários o controle e as concessóes econômicas e políticas do Estado, reforçando o poder local através da rede de núcleos urbanos (aglomeração de pessoas), para organizar minimamente o mercado de trabalho e para atribuir hierarquia aos núcleos urbanos através da circulação (amplitude e intensidade dos fluxos de bens e serviços), dando maior expressividade aos estoques, fluxos e relaçôes econômicas entre as escalas locais e regionais. Desse modo, a urbanização ou "o núcleo urbano é um elo na cadeia de mobilização, extração e concentração do produto excedente” (p. 369).

Becker lembra-nos ainda que a região Amazônica viveu a emergência de múltiplas formas de urbanização no passado, mas foram os grandes projetos, a criação da Zona Franca de Manaus em 1967 e o Programa Grande Carajás (exploração mineral), planejado na década de 1970 e lançado oficialmente em 1982, que promoveram o fortalecimento dos níveis intermediários de urbanização. Assim, a rede de algumas cidades mais dinâmicas passaria a montar e manter uma base econômica urbana mais diversificada que outras, o que corroboraria, na noção de arranjos urbanos intermediários, a existência de cidades com maior força de intermediação.

Outro elemento que completa esta discussão é o tipo de articulação do espaço rural com o urbano. Cano (2002), baseando-se em Celso Furtado, nos Ensaios sobre a formação econômica regional do Brasil, chamará a atenção para o fato do desenvolvimento rural brasileiro ter ocorrido via "agricultura itinerante", ou seja, pela 
expansão da fronteira móvel, sempre sujeita a negócios oportunistas e não fixando condiçôes de vida necessárias à sobrevivência da população rural como um todo. Nesse sentido, a dispersão espacial de cidades seria uma tendência estimulada tanto pela concentração da propriedade da terra como pelo avanço da fronteira móvel.

Ainda de acordo com Cano (2002), após o esgotamento de cada ciclo expansionista da fronteira agrícola, e à medida que outro vai se impondo, a concentração fundiária encontra como contra face a profusão de minifúndios, mas sem gerar oportunidades econômicas efetivas para pequenos proprietários e trabalhadores rurais, restando-lhes muitas vezes, como única alternativa, a migração para as cidades. Desse modo, em decorrência do modelo de modernização agrícola estabelecido no Brasil após 1970, tais fluxos migratórios em direção às cidades alcançaram o auge precocemente. Daí a noção de arranjos urbanos intermediários captar também esse aspecto histórico que levou ao deslocamento espacial, no sentido rural-urbano, importantes parcelas da população brasileira.

No período 1980-2010, tratado neste artigo, foram priorizadas as iniciativas de desenvolvimento territorial com maior inserção externa das regiôes rurais, devido especialmente ao "efeito China". Explicitou-se, então, uma forte contradição entre a expansão da fronteira agropecuária e a exploração extensiva (espacialmente) e intensiva (ecologicamente) da base de recursos naturais, já que a produtividade náo resultou apenas dos ganhos obtidos por hectare cultivado, mas também da maior facilidade em manter a itinerância territorial como soluçáo de conjunto para o crescimento da agricultura brasileira, de acordo com Cano (2002).

Considera-se, apoiando-nos nesses autores, a emergência de arranjos urbanos intermediários no Brasil como algo que pode decorrer de um processo de "urbanização precoce", tal como asseverou Cano (2002), mas que também se associa aos estímulos do Estado à "urbanização da fronteira" para dar suporte à sua rápida ocupação, tal como salientou Becker (1985). Em alguma medida, cidades que hoje chamamos de intermediárias são, na verdade, herdeiras de tais processos mais por falta de opção que por escolha própria.

No que tange à terceira relação, entre arranjo urbano intermediário e cidades intermediárias, recorremos a Milton Santos (2009) e suas noçôes de "Regiôes agrícolas que contém cidades" e "Regiôes urbanas que contém atividades rurais" para caracterizar a importância dos novos arranjos urbanos no contexto territorial. Assim, como ressalta o autor, a chave para decifrar essas regióes é entendê-las a partir do tipo de relaçóes desenvolvidas no espaço regional, sendo isto mais importante que o tamanho da cidade.

Santos (2008a) alerta-nos também para o fato de que "a força regional (...) não é o resultado apenas da presença de serviços frequentemente induzidos por interesses distantes; ela é o resultado de fatores intra-regionais...” (p. 181). Em seguida, noutro trabalho, Santos (2008b) aponta para a necessidade de se rever a ideia convencional de zona de influência (ou hinterlândia) e de levar em conta "os novos mecanismos geográficos" (p. 128). Salienta ainda que "a rede urbana é cada vez mais diferenciada, cada vez mais complexa", o que requer que se superem as simplificaçôes conceituais. 
As "cidades locais", sendo aquelas que, no seu entender, exercem o menor nível hierárquico na rede urbana, por exemplo, mudaram de conteúdo nos últimos anos (após 1990), substituindo rapidamente atividades tradicionais por novas especialidades (serviços). Na visão desse autor, as "cidades locais" são mais cidades no campo que cidades do campo. E afirma que o fortalecimento das cidades intermediárias traz uma nova e paradoxal tendência:

Neste período em que há o fortalecimento das cidades intermediárias ligadas às novas formas de produçáo e consumo, um fato para o qual nem temos voltado a nossa atençáo, merece ser realçado: é que no Brasil se dá, ao mesmo tempo, uma tendência à metropolização e à desmetropolizaçáo. (Santos, 2008a, p. 128)

Vão no mesmo sentido as observaçóes de Jordan e Simioni (1998), de que é impossível uma definição única e universal das cidades intermediárias. O importante é dar conta da diversidade de situaçóes existentes nos países latino-americanos, o que poderia ensejar uma análise sobre até que ponto, segundo os autores, houve uma reversão de polarização presente historicamente em nossos sistemas urbanos.

... en este escenario, las ciudades intermedias de los países de la región surgen como lugares privilegiados tanto para el crecimiento económico como para la articulación de políticas de decisiva trascendencia en el ámbito de la producción agropecuaria, industrial y de servicios ${ }^{1}$. (Jordan \& Simioni, 1998, p. 11)

Não é sem motivo que vários pesquisadores brasileiros consideram as cidades médias como elos importantes para o estudo dos espaços urbanos diferenciados, reconhecendo que é "preciso avançar na consolidação de critérios mais consistentes para a definição e identificação das cidades médias brasileiras”, indo além do critério demográfico.

Entre os critérios em discussão, podemos destacar a relevância regional que nos remete à forma como as cidades interagem e se inter-relacionam com as outras ao seu redor, como suas semelhantes e com as metrópoles. Nesse critério, é fundamental a compreensão da rede urbana. (Vieira, Nunes \& Guimarães, 2010, p. 61 - grifo dos autores)

Dessa maneira, para além da discussão sobre o conceito de cidade, faz-se mister discutir o grau de mediação entre as cidades e o fenômeno que pauta as transformaçôes nas hierarquias urbano-regionais. É a direção de tais transformaçôes que, em última análise, acaba influindo na importância de um conjunto de cidades em detrimento ou em beneficiamento de outro, justamente por essa maior capacidade de mediação que um determinado conjunto adquire enquanto outro perde. Então, mais que apenas reunir um conjunto de cidades grandes, médias e pequenas pelos vínculos pré-estabelecidos na rede urbana, importa o modo como elas se inter-relacionam e propiciam a criaçáo de um espaço urbano-regional diferenciado.

Num sentido rigoroso, as cidades intermediárias não se confundem conceitualmente com as cidades médias, mas, na prática, sim, à medida que os arranjos 
intermediários as abrange em boa proporção. O que denominamos de arranjo urbano intermediário reflete mais os interesses socioeconômicos sobre o território, com as cidades intermediárias cumprindo um papel de suporte e articulação dentro do arranjo. Moura (2009) chama atenção para aspectos como esses quando define os Arranjos Urbano-Regionais, sendo estes:

unidades concentradoras de população, relevância econômico-social e infraestrutura científico-tecnológica, com elevada densidade urbana, forte articulação regional e extrema complexidade, devido à multiplicidade de fluxos multidirecionais de pessoas, mercadorias, conhecimento e de relaçôes de poder que perpassam seu interior, participando de modo mais integrado nos âmbitos estadual, nacional e internacional, como os principais elos de inserção na divisão social do trabalho. (Moura, 2009, p. 1)

Já os arranjos urbanos intermediários, no nosso caso, correspondem a subgrupos ou novos agrupamentos urbanos pertencentes a um contexto espacial em que as cidades estáo mais dispersas, devido especialmente ao tipo de atividade econômica realizada, tais como a agroexportação, a mineração e os investimentos em grandes obras de infraestrutura. O elemento básico desses arranjos é a existência de uma grande área para a exploração de determinada economia especializada, o que facilita a dispersão das cidades dos arranjos urbanos pelo território, como também para além das aglomeraçóes concentradas dos arranjos urbano-regionais. Sendo assim, os arranjos urbanos intermediários teriam duas funçôes precípuas: (i) obter capacidade de mediaçáo espacial interurbana, local-regional, para adensar as relaçóes socioeconômicas no território e (ii) desenvolver capacidade de interação com cidades distantes, em decorrência dos fluxos extralocais que os empreendimentos lá instalados geram, nacional e internacionalmente.

Nessa concepção, os arranjos urbanos intermediários são complementares ou mesmo suplementares em relação aos arranjos urbano-regionais. Melhor ainda, são lugares dispersos cuja populaçâo, num primeiro movimento, aflui em direção aos arranjos urbano-regionais, em virtude da fixação de uma grande infraestrutura de suporte às atividades econômicas especializadas desenvolvidas no território e, num segundo movimento, pode refluir para os arranjos intermediários doutros lugares na região, atendendo a estímulos secundários. As cidades com maior capacidade de mediação-interação se situariam entre o lugar disperso e o concentrado, o que tem a ver com o balanço entre ganhos e perdas de centralidade do arranjo urbano, quando influenciado por certos vetores de mudanças.

O balanço entre perdas e ganhos de centralidade, nesse caso, serve para mostrar que as cidades redistribuem posiçóes e funções num território cuja urbanização é dispersa, fechando, assim, o elo entre o urbano e o regional. Os arranjos urbanos intermediários, neste sentido, especificam mais bem esse elo ao influírem na produção de novas hierarquias urbanas por meio das cidades que ganham centralidade e, por conseguinte, acumulam algum poder de comando em resposta (reflexa) aos níveis hierárquicos superiores metropolitanos, inclusive, passando a contar com uma estrutura intra-urbana ampliada. 
Em síntese, como o processo de urbanização reflexa está sujeito às vicissitudes do capital -em que os interesses capitalistas hegemônicos são transmitidos desde as áreas metropolitanas, transgredindo as relaçóes hierárquicas herdadas de períodos anteriores- as cidades intermediárias acabam encontrando maiores dificuldades para afirmar sua importância regional. Daí ser necessário ter em conta a formação de novos arranjos urbanos em áreas de urbanização dispersa para compreender as cidades intermediárias dentro dos novos processos de (re)hierarquização, a fim de averiguar como afetam a efetividade das políticas nacionais de desenvolvimento regional.

\section{Novas determinaçóes urbano-regionais: os fatores macroestruturais e as macrodecisóes de investimento na formaçáo de arranjos urbanos intermediários em regióes brasileiras}

$\mathrm{Na}$ seção anterior, considerou-se as cidades intermediárias como um elemento importante na compreensão da dinâmica interurbana nas áreas não metropolitanas. Com a definição de arranjos urbanos intermediários buscamos evidenciar a transferência parcial de poder de comando entre e intra níveis hierárquicos urbanos: saindo do superior, passando pelos intermediários concentrado e disperso e chegando, em menor monta, ao nível inferior. As cidades intermediárias demandam dos arranjos urbanos um porte escalar para exercer tais articulaçôes.

O objetivo desta seção é mostrar que os niveis intermediários urbanos aumentaram de volume no período pós-1990. As macrodecisóes de investimento requeridas em apelo aos interesses distantes (mercado mundial de commodities, por exemplo) fizeram com que esses níveis ganhassem funçóes, formas e mecanismos de interação territorial diferenciados. Há, nesse contexto, uma reação regional que ocorre em funçáo do acúmulo de poder de comando dum conjunto de cidades, para atender diligentemente ao comando hierárquico metropolitano (financeiro, imobiliário, exportador, etc.). A capacidade de intermediação (de bens e serviços) de algumas cidades fortalece esse propósito.

Nossa hipótese é que as cidades intermediárias cumprem, sim, um papel nas hierarquias urbano-regionais do Brasil, mas é um papel ancilar. A nosso ver, são os fatores macroestruturais e as macrodecisóes de investimento, como pontuaremos a seguir, que engendram a urbanização reflexa, sujeitando os arranjos urbanos intermediários à reproduçáo de heterogeneidades estruturais e socioespaciais que limitam o papel das cidades intermediárias.

O Brasil, com as reformas neoliberais e a abertura ao exterior da economia iniciadas nos anos de 1990, enfrentou a forte queda do saldo da balança comercial dando maiores incentivos às exportaçóes de produtos primários, promovendo uma série de transformaçôes produtivas nas áreas de expansão da fronteira agrícola e mineral. Já nos anos 2000 em diante, as obras de infraestrutura rodoferroviárias passaram a constituir os vetores principais de consolidação de um processo de racionalizaçáo logística do espaço que verticalizou os territórios, tornando-os predominantemente urbanos à medida que são regulados de fora pelo comando hegemônico do capital transnacional e regulados de dentro pelo capital nacional (estatal e privado), através do Programa de Aceleraçáo do Crescimento (PAC), do governo federal. 
FIGURA I | Evoluçáo da participação porcentual do VALOR dos cinco principais produtos da pauta exportadora do Brasil à China (2001-2015)

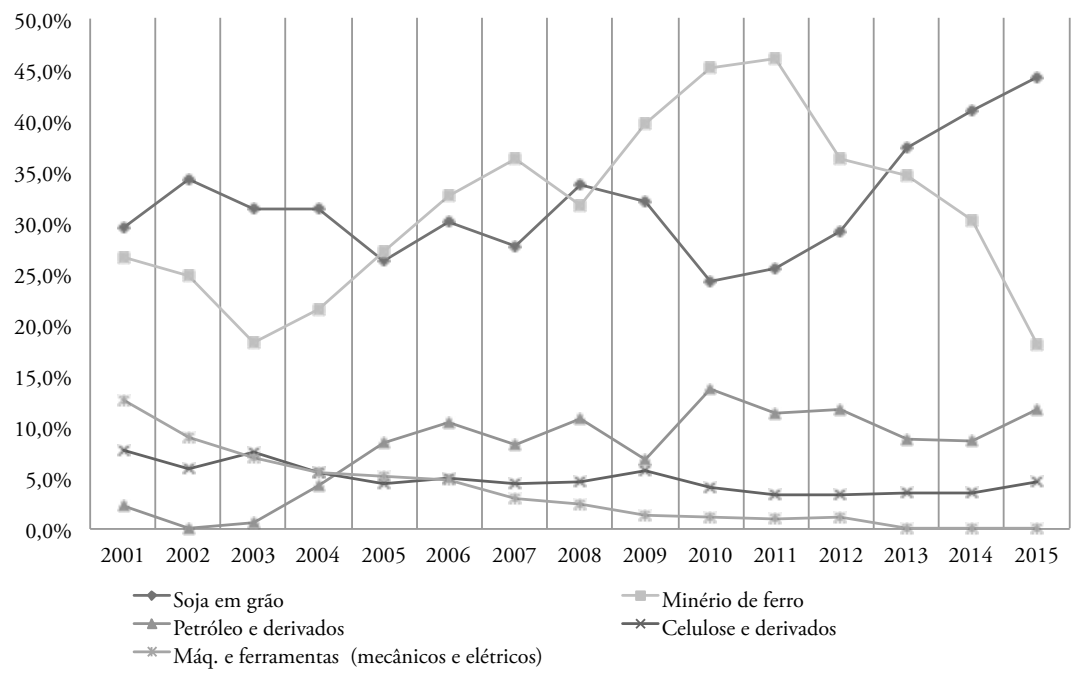

FONTE MINISTÉRIO DO DESENVOLVIMENTO, INDÚSTRIA E COMÉRCIO EXTERIOR (MDIC) - ELABORAÇÃO PRÓPRIA

O "efeito China", que se evidenciou no período 2003-2014, mudou o padrão de inserção externa da economia brasileira. A análise da pauta exportadora do Brasil para China (figuras 1, 2 e 3) não deixa dúvidas. Verificou-se uma participação crescente de três commodities -soja, minério de ferro e petróleo- entre os cinco principais produtos exportados aos chineses. O Brasil que exportava à China 3,19 milhóes de toneladas de soja em 2001, passa a exportar 40,9 milhóes em 2015. No caso do minério de ferro, de 28 milhóes de toneladas em 2001, passa a exportar expressivos 185,2 milhóes em 2015. Isso produziu efeitos no reordenamento territorial consideráveis, com influência marcante nas hierarquias urbanas das regiōes Centro Oeste, Norte e Nordeste do Brasil.

Ao mesmo tempo, há queda acentuada e até eliminação da participação na pauta exportadora brasileira de produtos de maior valor agregado, como máquinas e ferramentas para aparelhos mecânicos e elétricos, com a consequente maior dependência das importaçôes de produtos automotivos, eletrônicos e máquinas e equipamentos (tabela 3) da China. Em 2001, o valor em dólares das exportaçóes brasileiras em máquinas e ferramentas para aparelhos mecânicos e elétricos era da ordem de US\$ 228,7 milhóes e passou a US\$ 468,2 milhóes em 2012, deixando de exportar nos anos seguinte até 2015. De acordo com os dados do Informe China-Brasil Update (2015), o Brasil tem uma dependência relevante de importaçóes chinesas (48,0\%), muitas das quais se destinam, sobretudo, à Região Sudeste $(54,6 \%)$ e ao estado de São Paulo, que participa com $84,2 \%$ das importaçóes sobre a corrente de comércio Brasil-China em 2013. 
tabela 3 Brasil e China - Corrente de comércio exterior e dependência de importaçóes da China pelo Brasil, por regiáo (2014)

\begin{tabular}{|l|c|c|c|c|}
\hline \multirow{2}{*}{ REGIÃo } & $\begin{array}{c}\text { (A) CORRENTE } \\
\text { (US\$ MILHÓES) }\end{array}$ & $\begin{array}{c}\text { PARTICIPAÇÃo } \\
\text { REGIONAL }\end{array}$ & $\begin{array}{c}\text { (B) } \\
\text { IMPORTAÇÓES } \\
\text { (US\$ MILHÓES) }\end{array}$ & $\begin{array}{c}\text { DEPENDÊNCIA } \\
\text { DAS } \\
\text { IMPORTAÇÓES } \\
\text { CHINESAS (\%) }\end{array}$ \\
\cline { 2 - 5 } & $(\mathbf{A})$ & $\%$ & $(\mathbf{B})$ & $(\mathbf{B} / \mathbf{A})$ \\
\hline Sudeste & 34.380 & $44,2 \%$ & 18.758 & 54,6 \\
\hline Sul & 18.259 & $23,5 \%$ & 9.460 & 51,8 \\
\hline Norte & 10.543 & $13,5 \%$ & 5.388 & 51,1 \\
\hline Centro-oeste & 9.349 & $12,0 \%$ & 931 & 10,0 \\
\hline Nordeste & 5.329 & $6,8 \%$ & 2.801 & 52,6 \\
\hline Brasil & 77.860 & $100,0 \%$ & 37.338 & 48,0 \\
\hline
\end{tabular}

FONTE INFORME CHINA-BRASIL UPDATE, EDIÇÃO N ${ }^{\circ}$ I I (20 I 5 )

A mudança de padrão de inserção externa do Brasil imprimiu modificaçóes na divisão inter-regional do trabalho, pois os interesses industriais chineses concentraram-se quase exclusivamente na maior região metropolitana do país, com $46 \%$ dos grandes projetos de investimentos localizados em São Paulo, segundo o Boletim de Investimentos Chineses no Brasil (2014). Consequentemente, isso levou à "reprimarização", isto é, à maior dependência da participação de produtos primários na pauta exportadora brasileira. O setor exportador nacional tenta compensar a dependência da pauta importadora de produtos industriais chineses e de outros países (Estados Unidos e europeus) com a venda das commodities.

FIGURA 2 Evoluçáo da participação porcentual do volume das exportaçóes de soja em gáos e minério de ferro do Brasil à China (2001-2015)

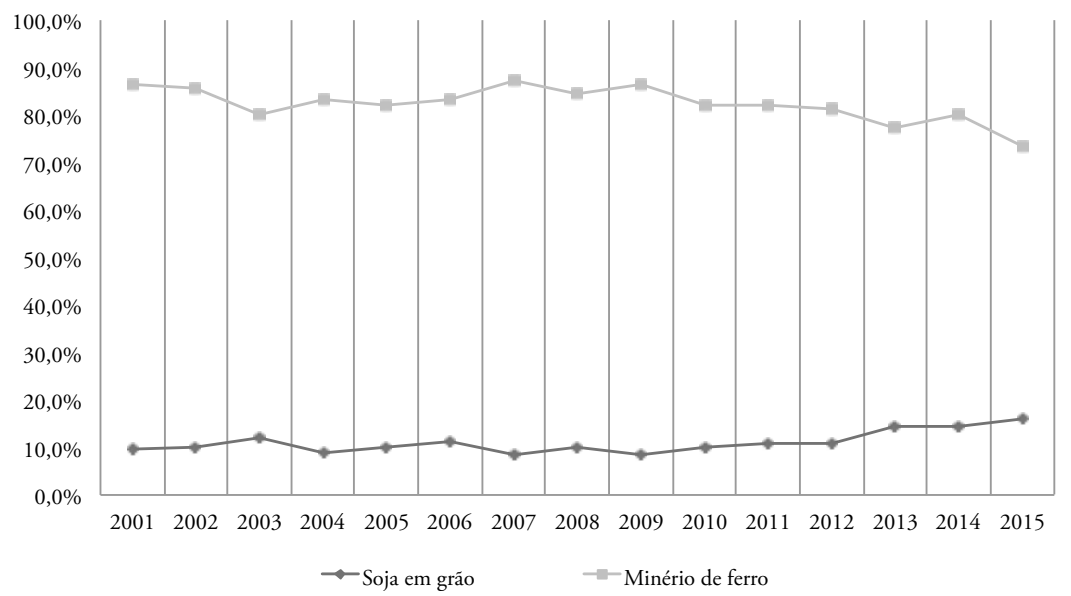

FONTE MINISTÉRIO DO DESENVOLVIMENTO, INDÚSTRIA E COMÉRCIO EXTERIOR (MDIC) - ELABORAÇÃO PRÓPRIA 
FIGURA 3 | Evolução da participação porcentual do vOLUME das exportaçóes de petróleo e derivados, celulose e derivados e máquinas e ferramentas do Brasil à China (2001-2015)

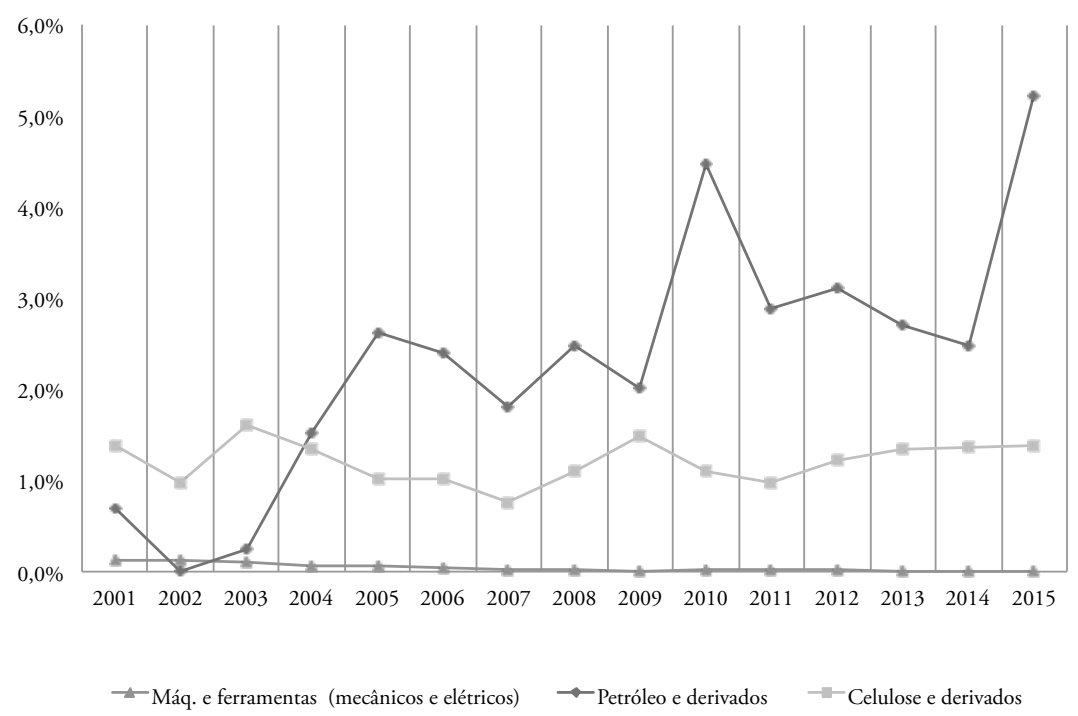

FONTE MINISTÉRIO DO DESENVOLVIMENTO, INDÚSTRIA E COMÉRCIO EXTERIOR (MDIC) - ELABORAÇÃO PRÓPRIA

Nesse contexto, boa parte das cidades situadas nas áreas não metropolitanas se tornaram verdadeiras "plataformas de exportação", com serviços específicos e especializados, dada a intensidade do capital aplicado nos processos extrativistas da indústria mineral e do petróleo, e na agricultura mecanizada. A mineração atinge especialmente a região amazônica e a soja, a Região Centro-Oeste e a Fronteira Ampla.

O documento "Projeçôes do Agronegócio", elaborado pelo Ministério da Agricultura, Pecuária e Abastecimento (MAPA), do Governo federal, em 2013, indica que "entre 2013 e 2023 a produção de grãos pode crescer entre 20,7\% e 34,3\%, enquanto a área deverá expandir-se entre 8,2 e 21\%” (Brasil/MAPA, 2013, p. 68). E, de acordo com o Mapa, o mercado interno também reagiria a esta expansão, sendo que "atualmente, $52,0 \%$ da soja grão produzida é destinada ao consumo interno, e do milho, 66,7\%” (Brasil/MAPA, 2013, p. 68). Ou seja, tais projeçóes oficiais mostram que o mercado interno voltaria a crescer e seria o fiel da balança na expansão do setor agropecuário nacional nos próximos anos. O setor de serviços ligado ao agronegócio acompanharia essa tendência, porém, o setor industrial tende a diminuir ainda mais sua participação na pauta de exportaçôes. $\mathrm{O}$ efeito espacial dessa dinâmica econômica deve, portanto, reforçar a dispersão das cidades, dada a seletividade espacial das decisóes de investimento.

Para isso, também colabora o conjunto dos investimentos projetados no período 2006-2014, parte dele ainda em fase de execução. De acordo com as decisóes de investimento em infraestrutura, pode-se constatar na tabela 4 que aquelas dirigidas 
para os modais rodoferroviários avançaram significativamente no período 20112014, com a taxa de crescimento do investimento alcançando um patamar de $18,6 \%$ ao ano, elevando-se acima de quesitos como saneamento e energia elétrica.

TABela 4 | Brasil: Projeção do Investimento em Infraestrutura

\begin{tabular}{|c|c|c|c|c|}
\hline \multirow{2}{*}{ SETORES } & \multicolumn{3}{|c|}{ VALOR (R\$ BILHÃO) } & \multirow{2}{*}{$\begin{array}{c}\text { TAXA } \\
\text { CRESCIMENTO } \\
\text { (\% A.A) }\end{array}$} \\
\hline & 2006-2009 & $20 I I-20 I 4$ & VARIAÇÃo & \\
\hline Energia Elétrica & 104 & 139 & 35 & 6,0 \\
\hline Telecomunicaçōes & 62 & 72 & 10 & 2,8 \\
\hline Saneamento & 26 & 41 & 15 & 9,4 \\
\hline Logística & 55 & 129 & 74 & 18,6 \\
\hline Rodovias & 20 & 60 & 40 & 24,7 \\
\hline Ferrovias & 30 & 51 & 21 & 11,4 \\
\hline Portos & 5 & 18 & 13 & 26,6 \\
\hline Infraestrutura (Total) & 247 & 381 & 134 & 9,0 \\
\hline
\end{tabular}

FONTE BNDES (2OII) - VISÄO DO DESENVOLVIMENTO, $\mathrm{N}^{\circ} 92$

Os investimentos do PAC, relacionados ao Programa de Investimento em Logística (PIL), destacam as Ferrovias: as obras de infraestrutura das ferrovias Norte-Sul -que atenderão aos municípios de Aguiarnópólis-to e Anápolis-Go)-, a Ferrovia de Integração do Centro-Oeste -que atenderá aos municípios de Uruaçu-GO, Lucas do Rio Verde-mt e Vilhena-Ro- e a Ferrovia de Integração Oeste-Leste -que visa atender aos municípios de Figueirópolis-To e Ilhéus-BA-. E obras de Rodovias: com construção da BR-163 e a BR-158 pretende-se atender aos estados do Pará, Mato Grosso, Goiás e Mato Grosso do Sul; com a BR-153, os estados do Pará, Tocantins e Goiás; e com as radiais BR-60 e 70, o Distrito Federal, Goiânia, Mato Grosso e Mato Grosso do Sul. Através dessas conexóes, eleva-se o grau de seletividade e assimetria espaciais em diferentes áreas das regióes Norte, Centro-Oeste e Nordeste. A estimativa de gastos situou-se ao redor de $\mathrm{R} \$ 380$ bilhóes para o período 2011-2014, projetando uma taxa de investimento no setor da ordem de 2,5 a 3\% do рів (Produto Interno Bruto), segundo o Banco Nacional de Desenvolvimento Econômico e Social (BNDES, 2011). As figuras 4 e 5 dão uma noção dessas projeçóes.

Tais projeçóes indicam que o setor agropecuário, especialmente aquele voltado à produção de grãos, irá crescer nas áreas dos estados brasileiros do Maranhão, Tocantins, Piauí e Bahia, devendo "produzir próximo de 18 milhóes de toneladas de grãos em 2023 (aumento de 21,6\%) e [elevar a] área plantada de grãos entre 7 e 10 milhóes de hectares" (Brasil/MAPA, 2013, p. 71). Neste caso, o governo federal instituiu o decreto n. 8.447 de maio de 2015, que cria o Plano de Desenvolvimento Agropecuário do Matopiba² (PDA-Matopiba). Dentre as três diretrizes do plano, a primeira se refere ao "desenvolvimento e aumento da eficiência da infraestrutura logística relativa às atividades agrícolas e pecuárias” (Brasil, 2015, s/n.).

2 Acrônimo para os estados do Maranhão, Tocantins, Piauí e Bahia. 
FIgura 4 | Programa de Investimento em Logística (PIL) voltado às Ferrovias

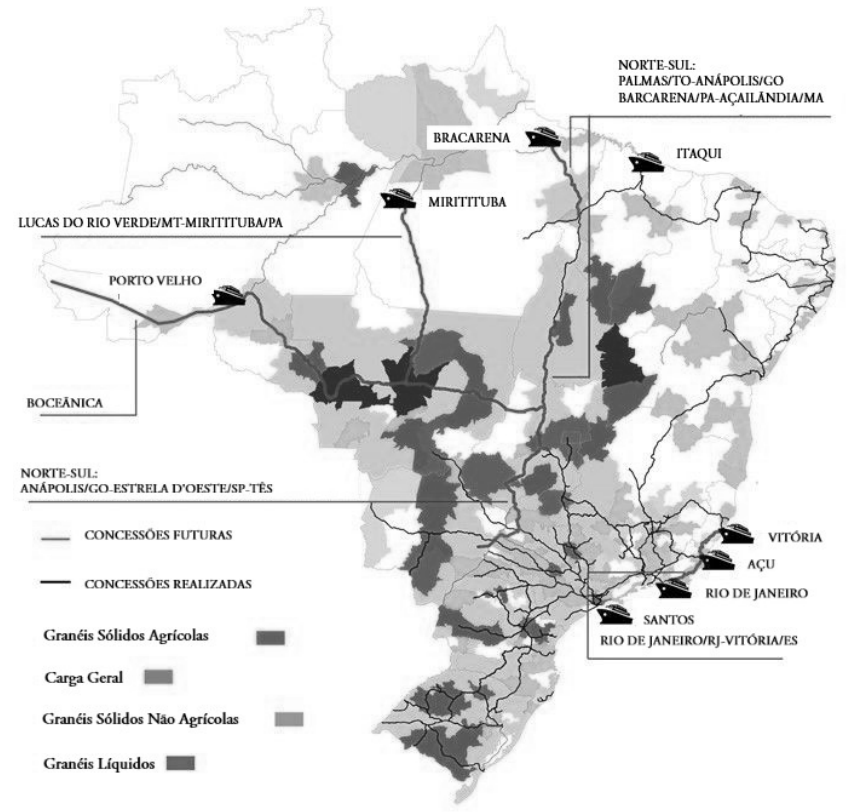

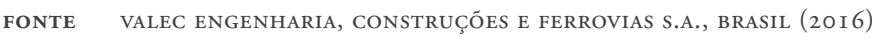

FIGURA 5 | Programa de Investimento em Logística (PIL) voltado ás Rodovias

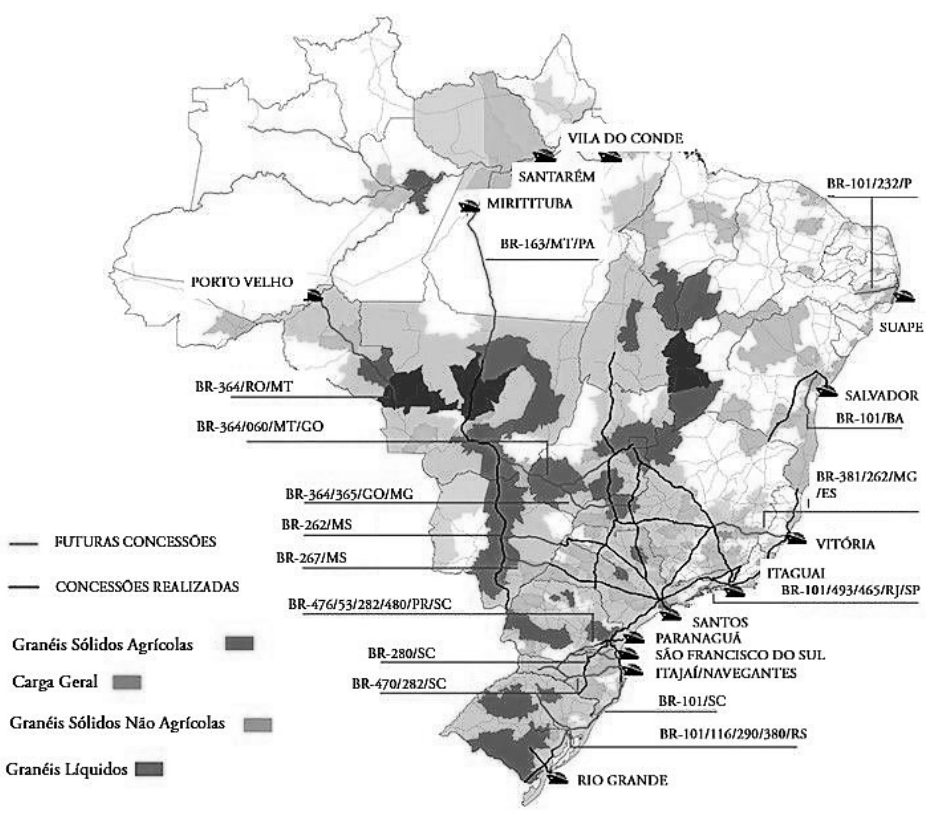

FONTE VALEC ENGENHARIA, CONSTRUÇÕES E FERROVIAS S.A., BRASIL (20I6) 
Os investimentos atuais em ferrovias nos mostram que este modal terá uma participação cada vez mais relevante no escoamento da produção agrícola do país. Na nova etapa do PIL, espera-se investir R \$ 86,4 bilhóes de um total de $\mathrm{R}$ \$ 327,6 bilhôes na expansão e operação da infraestrutura de transportes no período 2015-2018. Ou seja, o equivalente a $26,4 \%$ da previsão de investimentos. Chama a atenção, nessa nova etapa, o acordo firmado entre China, Brasil e Peru em torno da construçáo da ferrovia Bioceânica, visando à ligação entre os oceanos Atlântico e Pacífico para ampliar as possibilidades de escoamento da produção dos países sul-americanos.

Em boa medida, tais inversóes sobre os territórios fazem com que as cidades localizadas nas áreas não metropolitanas das regiôes Centro-Oeste, Nordeste e Norte elevem seu o incremento populacional urbano. Isto porque os investimentos em infraestrutura do PAC, relacionados aos grandes projetos de forte impacto no território -tais como usinas hidrelétricas, exploração mineral e projetos rodoferroviários- requerem a formação ou ampliação de núcleos urbanos, explicitando uma relação estreita entre a seletividade dos projetos no uso e controle da base de recursos naturais do território e a intensidade da urbanização nas áreas de fronteira no período pós-1990.

A partir daqui, utilizamos a tipologia de níveis hierárquicos para mostrar a intensidade da urbanização e ilustrar a discussão. A vantagem desse critério é que nos permite visualizar os níveis intermediários da urbanizaçáo de modo comparativo para diferentes regióes do Brasil e, em especial, para os espaços de expansão da fronteira agromineral, onde as cidades sáo agrupadas conforme a tipologia adotada.

Desse modo, pode-se observar, no figura 6, que houve um crescimento dos níveis intermediários da população urbana no Brasil desde 1970. Quanto à distribuição dos incrementos de população urbana, por grandes regióes, entre dois longos períodos (1950-1980 e 1980-2010), o figura 7 mostra o peso relativamente maior na participaçáo das regióes Norte, Nordeste e Centro-Oeste comparativamente ao período anterior.

FIGURA 6 | Crescimento dos níveis intermediários de urbanização no Brasil (1970-2010)

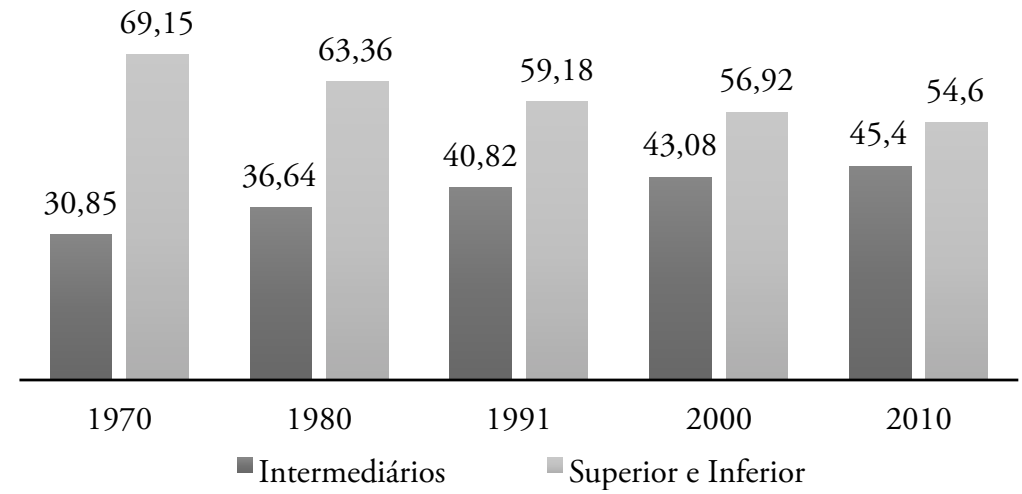

FONTE IBGE (2OIO) - ELABORAÇÃo PRÓPRIA 
FIGURA 7 Distribuição do incremento de população urbana por Grandes Regióes em dois períodos. Brasil = 100\%

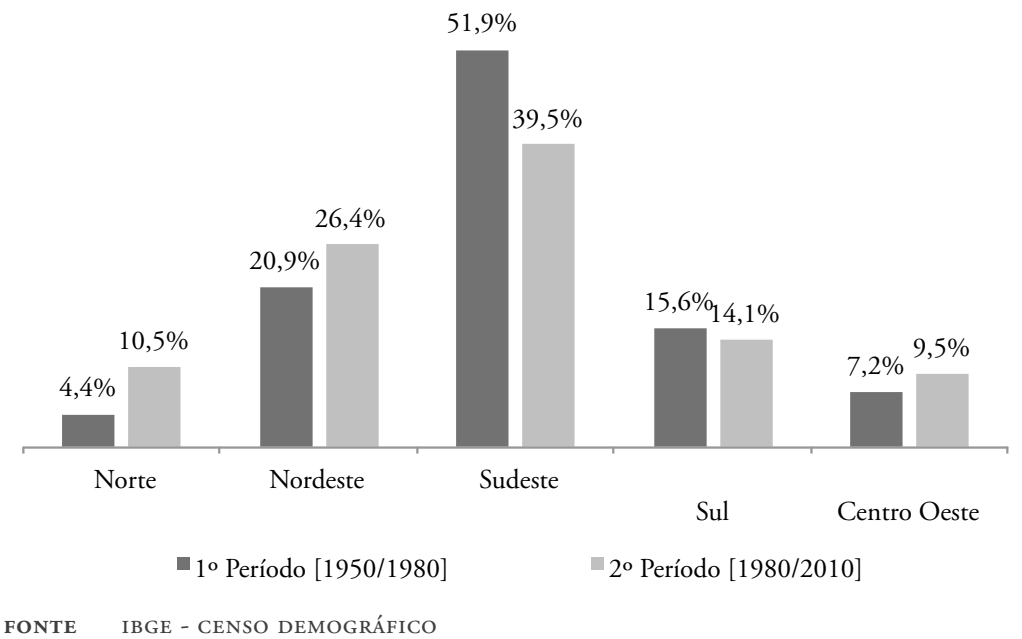

Na figura 8, por sua vez, observa-se que a intensidade da urbanização se concentrou no período em que tiveram lugar as políticas neoliberais (1980-2010), através da maior abertura da economia brasileira ao mercado internacional de commodities. Esta intensidade é medida pela razão entre o crescimento da população urbana e o crescimento da população total, sendo que a obtenção de um valor acima de 1,0 (um) significa que a população urbana intensificou seu crescimento, com índices superiores à da população total. \begin{tabular}{l|l} 
FIGURA 8 & $\begin{array}{l}\text { Intensidade da Urbanização em dois longos períodos no Brasil e em } \\
\text { suas cinco grandes Regiôes }\end{array}$
\end{tabular}

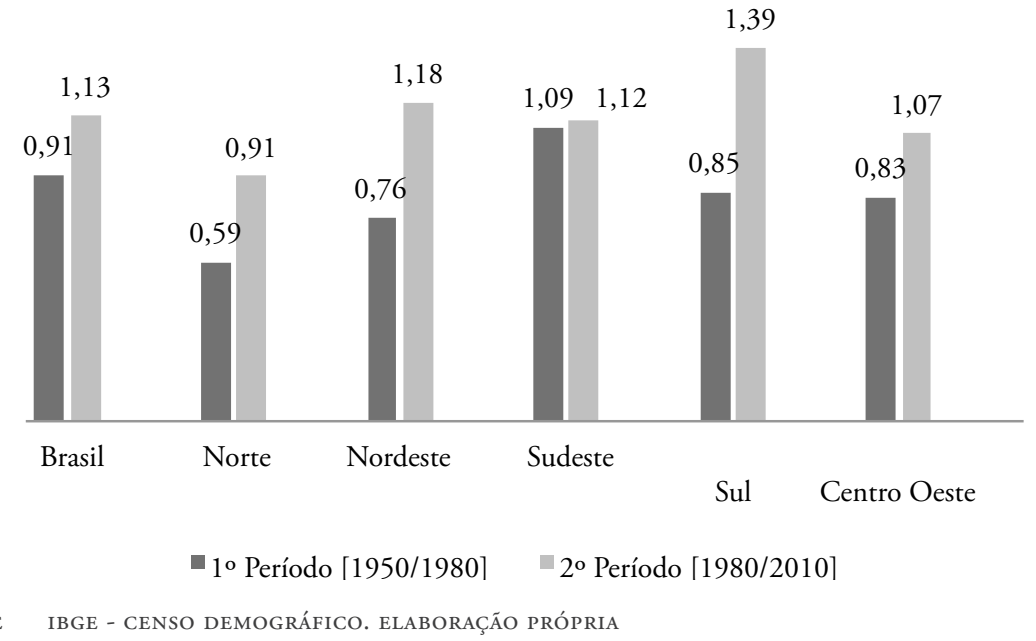


Em razão dos fatores macroestruturais e das macrodecisóes prevalecentes no período pós-1990, via o superciclo de commodities puxado pela China, as cidades intermediárias no Brasil passaram a traduzir, mais que qualquer outra, um processo de urbanização reflexa. Assim, a característica central do atual padrão de urbanização é ter dado sustentação a uma organização espacial com cidades de conteúdo agrícola moderno, que passam a contar com um segmento terciário (serviços) mais avançado e que, concomitantemente, tornaram-se mais dependentes de relaçóes socioeconômicas extralocais/regionais e de repasses e/ou investimentos governamentais. Um aspecto comum e decisivo que influi sobre o re-ordenamento territorial das regióes brasileiras e que reitera a emergência dos arranjos urbanos intermediários nas áreas não metropolitanas são os investimentos em obras de infraestrutura de largo alcance espacial. Tomaremos a seguir os casos da Fronteira Ampla e da Borda Amazônica para ilustrar a análise.

\section{Investimentos em infraestrutura na fronteira urbanizada do Cerrado e da Amazônia Oriental: o caso dos Arranjos Urbanos Intermediários da Fronteira Ampla e da Borda Amazônica}

Buscamos, na seção anterior, explicitar os fatores macroestruturais e as macrodecisōes de investimento que estão influenciando nas mudanças das hierarquias urbano-regionais. Os investimentos executados e previstos recentemente reforçam nossa análise, mostrando que os projetos de infraestrutura operam de acordo com a lógica de escoamento da produçáo primária (agropecuária, energética e mineral), provocando novos processos de re-hierarquizaçáo na rede urbana nacional.

Nesta seção, nosso objetivo é ilustrar a discussão sobre a emergência dos novos arranjos urbanos intermediários, chamando a atençáo para os efeitos espaciais das obras de infraestrutura em curso no Brasil. Numa região como a Amazônia Oriental, onde até a pouco tempo atrás as vias de acesso ou de escoamento da produçáo eram praticamente inexistentes ou precárias, com a expansão da fronteira agrícola, foi possível modernizar os modais de transporte e viabilizar atividades, aproveitando o suporte logístico de crescimento da base urbana.

A infraestrutura, no caso, dá sentido, fluidez, velocidade e rentabilidade ao território, incrementando a taxa de urbanização dos arranjos, até que algumas das cidades daquele contexto espacial adquiram força intermediadora suficiente, decorrente do aumento nos fluxos materiais e imateriais (serviços), para mudar de porte e alcançar um comando hierárquico com alguma relevância. No que tange aos arranjos urbanos intermediários, é mais comum que as centralidades urbanoregionais estejam subdividas em comandos complementares, entre duas ou mais cidades do mesmo arranjo. Cidades como Araguaína, Gurupi, Paraíso do Tocantins, Colinas do Tocantins, Guaraí, no estado do Tocantins (figura 9), que tiveram suas economias dinamizadas pela agroindústria, p. ex., adquiriram centralidade, mas sem alcançarem a importância de um centro regional. 
FIgURA 9 | Trechos rodoferroviários no estado do Tocantins

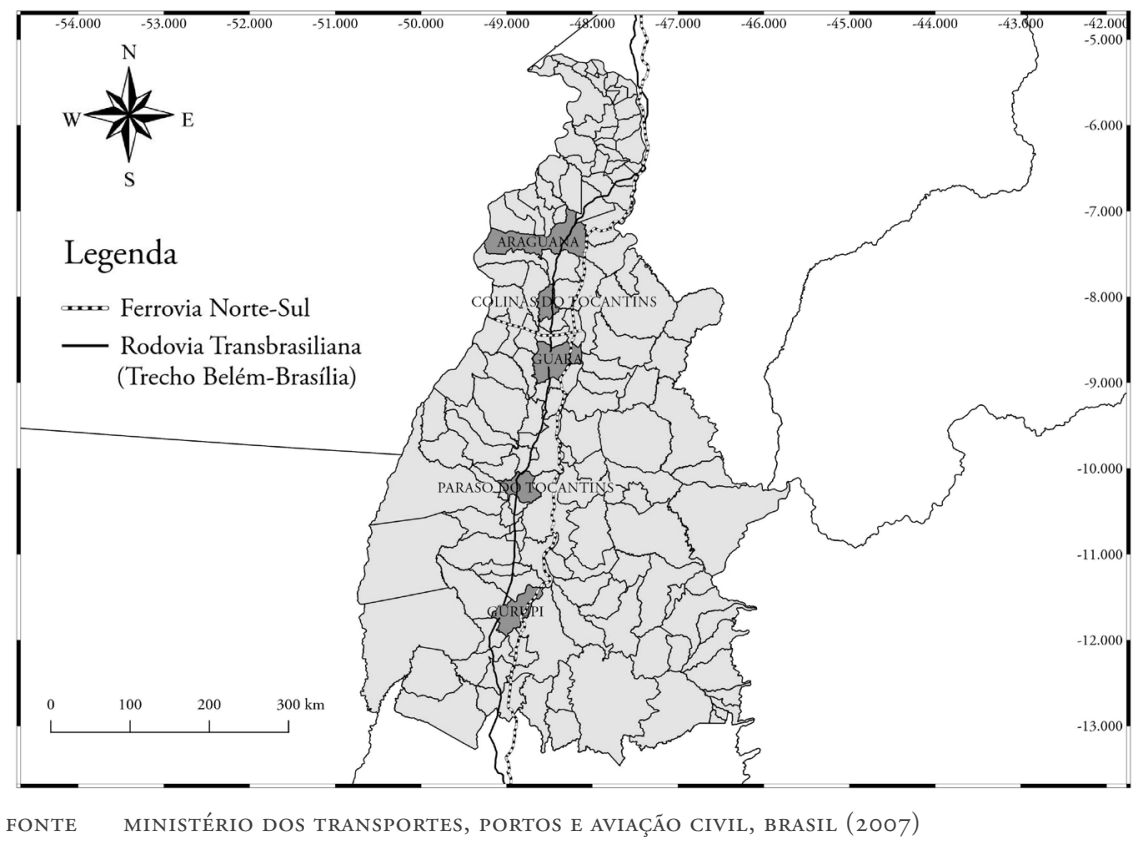

Na nova etapa do PIL, lançada entre 2014 e 2015, as regióes que receberão os maiores montantes de investimentos derivados da construção de ferrovias são exatamente as da fronteira agrícola. Além da ferrovia Norte-Sul, há também o plano de construção de uma ferrovia entre Rio Verde (MT) e Miritituba (РA), com a finalidade de melhorar o escoamento da produção agrícola do estado do Mato Grosso, e a já citada Ferrovia Bioceânica. Vale lembrar que quando a ferrovia Norte-Sul foi iniciada, ainda no governo do presidente José Sarney (1985-1990), o único trecho construído foi o que liga os municípios de Açailândia-ma e Imperatriz-MA, com 95 km. Durante oito anos de governo do presidente Fernando Henrique Cardoso (1995-2002) foram construídos mais $120 \mathrm{~km}$ entre Imperatriz-MA e Aguiarnópolis-To e uma ponte sobre o rio Tocantins, ligando os municípios de Estreito-MA e Aguiarnópolis-To. Desde 2007, ano de início do PAC, até maio de 2014, foram construídos $1.351 \mathrm{~km}$ de ferrovia.

No período atual, a construção e a melhoria de eixos viários existentes consolidam a fronteira agrícola como espaço de acumulaçáo, a fim de ampliar a competitividade do país no mercado de commodities frente à concorrência internacional. A figura 10 destaca o plano de expansão de um dos trechos da ferrovia Norte-Sul. 
Figura io | Plano de expansáo de ferrovias no Brasil: destaque para o trecho Barcarena (Pará)-Açailândia (Maranhão), situado no extremo norte da ferrovia Norte-Sul (EF-I 5 I)
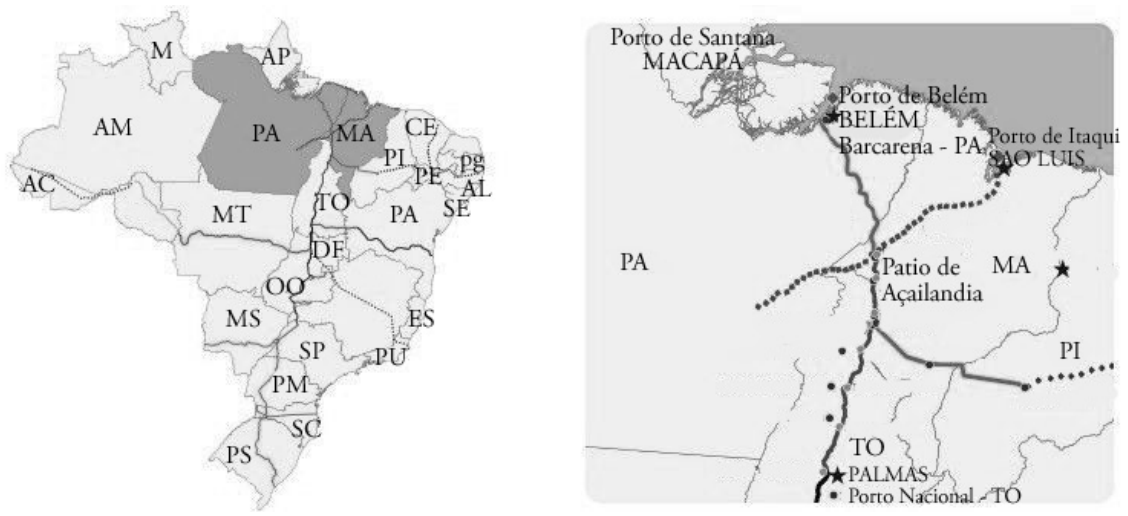

FONTE VALEC ENGENHARIA, CONSTRUÇŌES E FERROVIAS S.A., BRASIL (2OI6)

Os municípios da região que sediaram pátios dos modais da Ferrovia 151 (Norte-Sul) passaram a ganhar importância na realização de fluxos de mercadorias e pessoas. $\mathrm{O}$ trecho entre Açailândia-MA e Barcarena-PA, de $477 \mathrm{~km}$-cujo propósito é ligar a ferrovia ao porto de Vila do Conde-, permitirá que parte da produçáo regional seja enviada para o porto de Itaqui, em São Luís-MA, via ferrovia Carajás. Tais conexôes ampliam os processos espaciais e, simultaneamente, reforçam a verticalização do território ao acionarem o interior das regióes de fronteira para ligá-lo aos portos diretamente.

Salienta-se que essa dinâmica extrovertida vai além das áreas do Cerrado nordestino e do estado do Tocantins, as quais são vistas pelo governo brasileiro como a "última fronteira agrícola do mundo" (Brasil/Mapa, 2015). Obviamente, não se trata apenas disso, mas dos diferenciais de urbanização ao longo das últimas décadas que dão uma amplitude maior à região de fronteira. No estágio atual, incluímos parte da floresta amazônica, principalmente as áreas limítrofes a outros biomas e algumas outras áreas do Cerrado brasileiro no espaço que denominamos de fronteira ampla. Dessa forma, grande parte da Amazônia oriental, incluindo porçóes do estado do Pará e de Rondônia, estaria inserida nesses processos seletivos de reordenamento territorial da fronteira urbanizada.

Dada à extensão dos processos espaciais em curso, voltamos nossa atenção para os seus desdobramentos na Fronteira Ampla-que compreende os municípios dos estados do Mato Grosso do Sul, Mato Grosso, Goiás, Rondônia, Acre, Pará, Tocantins, Maranhão Piauí e Bahia- e na Borda Amazônica-que compreende os municípios dos estados do Mato Grosso, Goiás, Pará e Tocantins- para ilustrar a emergência de arranjos urbanos intermediários, que marcam diferenças regionais de crescimento urbano. Verifica-se na tabela 5 que há um crescimento demográfico do conjunto de cidades intermediárias desde 1970, mas esse crescimento persevera nesses subespaços regionais pós-1990. 
TABELA 5 | Taxa média geométrica (\%) de crescimento demográfico anual para cidades, por níveis hierárquicos e recortes espaciais selecionados

\begin{tabular}{|c|c|c|c|c|c|c|c|c|}
\hline \multirow{2}{*}{$\begin{array}{c}\text { NÍVEL } \\
\text { HIERÁRQUICO }\end{array}$} & \multicolumn{2}{|c|}{ BRASIL } & \multicolumn{2}{|c|}{$\begin{array}{c}\text { FRONTEIRA AMPLA } \\
\text { (COM RMS) }\end{array}$} & \multicolumn{2}{|c|}{$\begin{array}{c}\text { FRONTEIRA AMPLA } \\
\text { (SEM RMS) }\end{array}$} & \multicolumn{2}{|c|}{$\begin{array}{c}\text { BORDA } \\
\text { AMAZÔNICA }\end{array}$} \\
\hline & $\begin{array}{l}1970 / \\
2010\end{array}$ & $\begin{array}{r}2000 / \\
2010\end{array}$ & $\begin{array}{l}2000 / \\
2010\end{array}$ & $\begin{array}{l}2000 / \\
2010\end{array}$ & $\begin{array}{l}1970 / \\
2010\end{array}$ & $\begin{array}{l}2000 / \\
2010\end{array}$ & $\begin{array}{l}1970 / \\
2010\end{array}$ & $\begin{array}{r}2000 / \\
2010\end{array}$ \\
\hline superior & 2,76 & 1,73 & 4,7 & 2,78 & - & - & - & - \\
\hline $\begin{array}{l}\text { Intermediário } \\
\text { concentrado }\end{array}$ & 3,38 & 2,1 & 2,11 & 0,34 & 5,88 & 3,74 & 7,68 & 5,23 \\
\hline Inferior & 2,47 & 0,92 & 2,92 & $-0,37$ & 3,57 & 1,35 & 4,53 & 1,64 \\
\hline $\begin{array}{l}\text { Intermediário } \\
\text { disperso }\end{array}$ & 2,95 & 0,62 & - & $-1,45$ & 4,47 & 1,97 & 6,48 & 3,8 \\
\hline
\end{tabular}

NOTA OS TRAÇOS SIGNIFICAM QUE A POPULAÇÃO DO ANO BASE É IGUAL A ZERO

FONTE IBGE - VÁRIOS CENSOS

A figura 11, que mostra o número de armazéns de grãos, ilustra o cenário geral dessas frentes de expansão na Amazônia, em que é possível apenas distinguir os principais estados da Borda Amazônica, dentro da Fronteira Ampla, por meio da presença dos armazéns de grãos (pontos) localizados no Pará (PA), Tocantins (TO), Goiás (GO), Mato Grosso (MT) e Rondônia (RO). A concentração desses armazéns no subespaço serve à formação de nucleaçóes urbanas.

FIGURA I I | Biomas do Brasil e a distribuição territorial de armazéns de grão em 2010

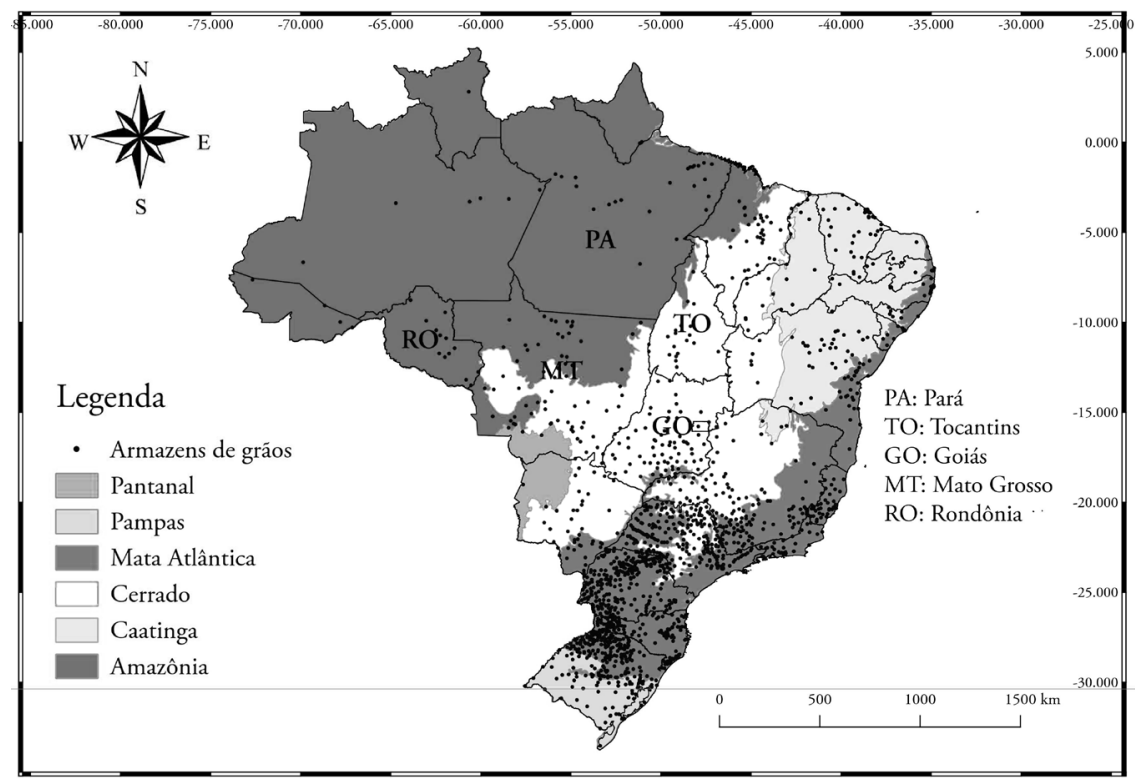

FONTE MINISTÉRIO DOS TRANSPORTES, BRASIL (2007) 
Entre 2000 e 2010, as cidades que compóem a Fronteira Ampla e a Borda Amazônica, apresentaram um crescimento anual de sua população superior ao verificado nos mesmos níveis hierárquicos para o Brasil. No caso dos níveis intermediários, o crescimento populacional foi mais significativo. A queda no crescimento anual, a partir dos anos de 2000, quando comparado ao crescimento desde a década de 1970, se explica pela redução da taxa de natalidade do país e pela abertura de várias frentes de expansão territorial naquelas regióes.

A emergência dos arranjos urbanos intermediários evidenciam o papel dos investimentos em infraestrutura, obras de logística rodoferroviária, como um dos principais determinantes dos novos comandos que surgem, forjando re-hierarquizaçóes urbano-regionais a partir de áreas não metropolitanas, dado que fatores como a localização de empreendimentos logísticos, as funcionalidades das obras, o escoamento de produção por diferentes direçôes do território nacional possibilitaram uma interação mais frequente entre cidades nas regiôes brasileiras situadas no bioma do Cerrado e na Amazônia Oriental, o que afetou o destino das suas populaçóes rural e urbana.

Concernente à população rural (tabela 6), constata-se sua concentração, em termos absolutos, no nível Inferior da hierarquia urbana da Borda Amazônica. A participação da população rural total nesse subespaço é de 76,5\% em 2000 e de $65,4 \%$ em 2010. Já nos níveis intermediários concentrado e disperso, a população rural aumentou de $23,1 \%$ para 34,2\%, respectivamente, entre 2000 e 2010 . No nível Superior, a população rural não cresceu, ficou em $0,4 \%$ da população rural total, respectivamente, no mesmo período. Observe-se, que, nesses dois últimos censos, apenas os níveis intermediários obtiveram aumento relativo maior de população rural, supostamente, porque as cidades tiveram um papel ativo na gestão das atividades rurais. No caso da populaçáo urbana (figura 12), os níveis intermediários se destacam.

TABELA 6 | Evolução da população rural nos estados da Borda Amazônica (1970-2010)

\begin{tabular}{|c|c|c|c|c|c|}
\hline $\begin{array}{c}\text { NÍVEL } \\
\text { HIERÁRQUICO }\end{array}$ & I970 & I980 & I99I & 2000 & 2010 \\
\hline Superior & - & - & 395.502 & 15.461 & 16.849 \\
\hline $\begin{array}{l}\text { Intermediário } \\
\text { concentrado }\end{array}$ & 148.984 & 426.721 & 311.003 & 309.087 & 478.507 \\
\hline Inferior* & 2.784 .464 & 2.857 .999 & 2.983 .931 & 3.050 .107 & 2.769 .376 \\
\hline $\begin{array}{l}\text { Intermediário } \\
\text { disperso }\end{array}$ & 329.437 & 657.495 & 839.176 & 612.570 & 966.723 \\
\hline $\begin{array}{l}\text { POPULAÇ } \\
\text { CONTAGE }\end{array}$ & STE NÍVEL & UIU A DO N & INTERMEDI & DISPERSO I & EVITAR DUPLA \\
\hline CENSOS & ÁFICOS/IB & ELABORAÇÃ & ÓPRIA & & \\
\hline
\end{tabular}


FIgURA I 2 | População urbana dos municípios situados nos níveis Superior, Inferior e Intermediários da Fronteria Ampla (FA) e da Borda Amazônica (BA), em milhóes de pessoas (1970-2010)

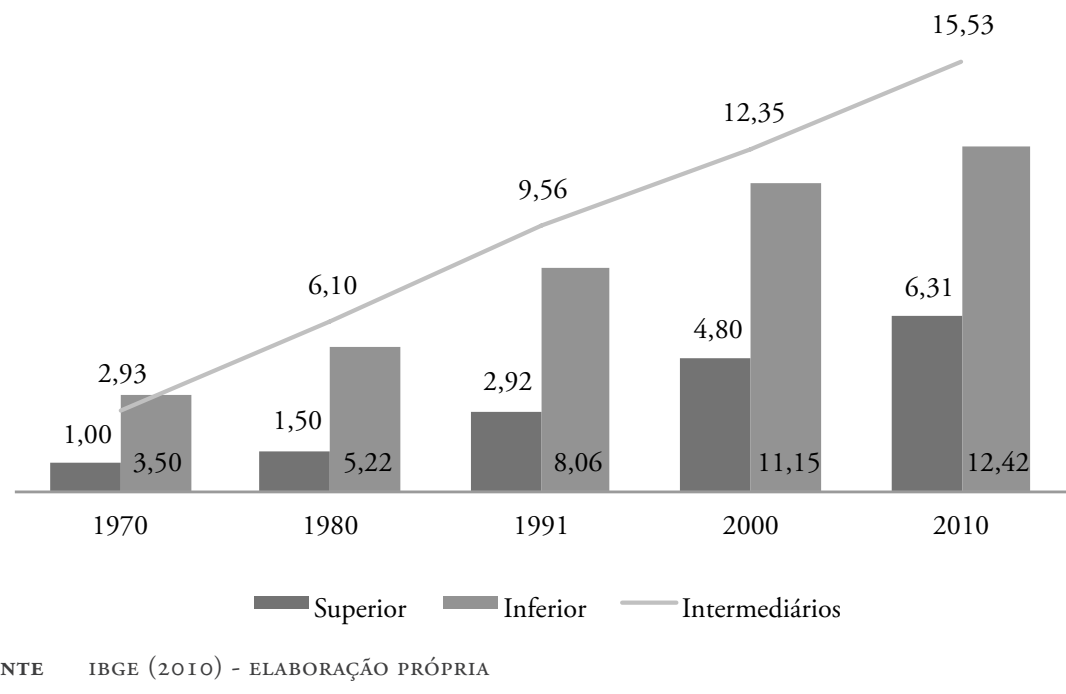

Verifica-se que a maior concentração da população urbana se dá nos níveis Intermediários concentrado e disperso, tanto no subespaço denominando de Fronteira Ampla como no da Borda Amazônica. Após 1990, ocorre aumento mais rápido de população urbana no nível Inferior, devido, supomos, ao efeito do crescimento da população urbana no nível Superior e nos níveis intermediários, indicando uma re-hierarquização urbana no subespaço da Fronteira Ampla, causada pela criação de maiores vínculos econômicos nesse subsistema.

No subespaço da Borda Amazônica, a partir dos anos 1990, não ocorre aumento de população urbana no nível Inferior no mesmo ritmo da Fronteira Ampla. De acordo com o critério demográfico usado, os municípios do nível Superior surgem apenas em 1991, mas crescem mais lentamente que os demais. Já a população urbana dos níveis Intermediários concentrado e disperso elava-se, vis-à-vis os níveis Superior e Inferior entre 2000 e 2010, com destaque para o maior aumento no ano de 2010. Essa intensificação do crescimento da população urbana nos níveis intermediários da Borda Amazônica também confirma, a nosso ver, um processo de re-hierarquização urbana.

De acordo com as taxas de urbanização dos dois subespaços, constata-se que as da Borda Amazônica superam as da Fronteira Ampla. Reitera-se, assim, o avanço de uma fronteira urbanizada como uma das principais consequências da re-hierarquização, que se origina de fora desse subespaço, influenciada pelos fatores macroestruturais já discutidos. No caso da Borda Amazônica, o ritmo de urbanização é mais intenso desde 1980, com taxas acima de 50\%, e se mantém crescendo (tabela 7). 
TAbela 7 | Evoluçáo das taxas de urbanização da Fronteira Ampla e da Borda Amazônica (1970-2010) (percentagem)

\begin{tabular}{|c|c|c|c|c|c|}
\hline SUBESPAÇO & I970 & I980 & I99I & $\mathbf{2 0 0 0}$ & 2010 \\
\hline Fronteira Ampla & 38,80 & 49,00 & 59,30 & 70,00 & 73,80 \\
\hline Borda Amazônica & 43,90 & 55,70 & 65,30 & 75,40 & 78,40 \\
\hline
\end{tabular}

FONTE CENSOS DEMOGRÁFICOS/IBGE. ELABORAÇÃO PRÓPRIA

Com relação ao cálculo dessas taxas de urbanização, esclarecemos que elas são uma composição (soma) das taxas de cada nível (Superior, Inferior e Intermediários Concentrado e Disperso). Por isso, os gráficos a seguir vão conter taxas de urbanização inferiores a $50 \%$. A intenção é mostrar quanto cada nível contribui para, digamos, urbanizar a fronteira, confirmando, desse modo, o papel dos níveis intermediários nesse aspecto central.

No subespaço da Fronteira Ampla, as taxas de urbanização vão de 38,8\% em 1970 para 73,8\% em 2010. De acordo com a composição das taxas de urbanização por nível hierárquico nesse período, elas se estabilizaram no nível Superior e diminuem o ritmo de crescimento no nível Inferior entre 2000 e 2010 . Somente em 2010 é que há um maior descolamento da taxa de urbanização dos níveis intermediários em relação aos demais, mas sua evolução é progressiva depois de 1991, quando passa a crescer a um ritmo mais constante. Ainda na tabela 7, observa-se que a evolução das taxas de urbanização no subespaço da Borda Amazônica, que vão de 43,9\% em 1970 para 78,4\% em 2010, são superiores às da Fronteira Ampla.

Finalmente, os figuras 13, 14 e 15, a seguir, ilustram exatamente o processo de avanço da fronteira urbanizada, comandado pelos níveis intermediários, o que constatamos por meio do crescimento absoluto da população urbana e pelas taxas de urbanização, considerando a comparação entre os subespaços adotada aqui.

FIgURA I 3 | População urbana dos municípios situados nos níveis Superior, Inferior e Intermediários da Borda Amazônica (BA), em milhóes de pessoas (1970-2010)

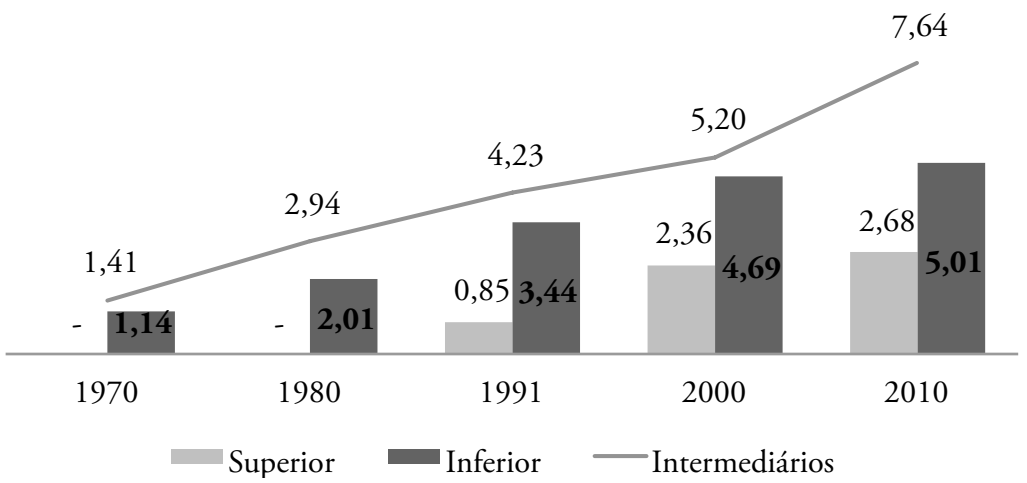

FONTE IBGE (2OIO) - ELABORAÇÃo PRÓPRIA 
FIgURA I4 | Fornteira Ampla: taxas de urbanização dos níveis hierárquicos Superior, Inferior e Intermediários (1970-2010)

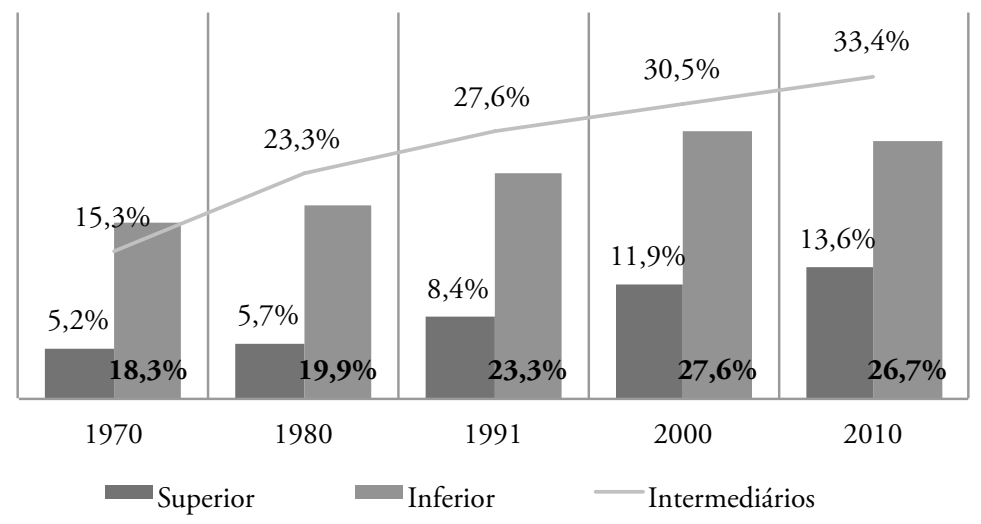

FONTE IBGE (2OIO) - ELABORAÇÃo PRÓPRIA

FIgURA I5 | Borda Amazônica: taxas de urbanização dos níveis hierárquicos Superior, Inferior e Intermediários (1970-2010)

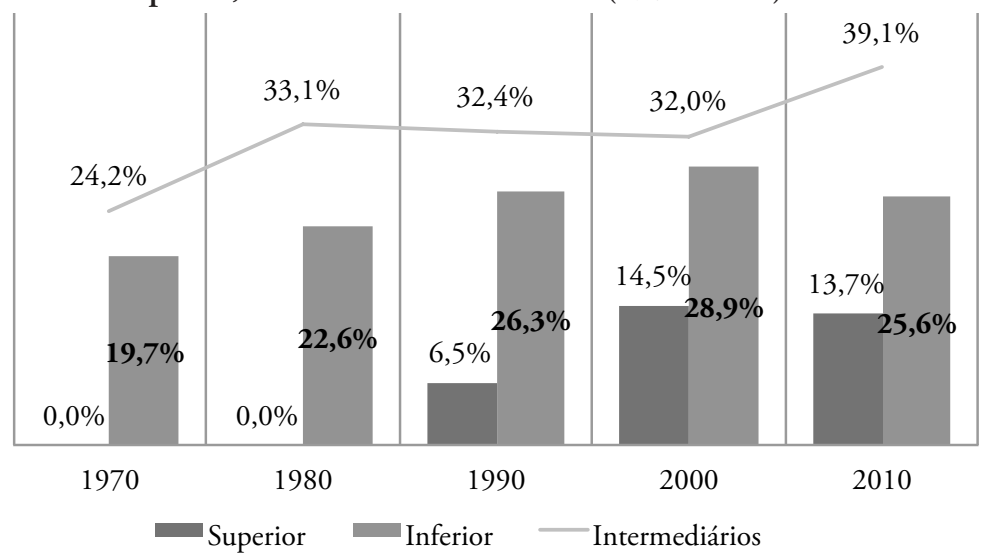

FONTE IBGE (2OIO) - ELABORAÇÃO PRÓPRIA

De acordo com a distribuição da população urbana (figura 13) e composição das taxas de urbanização na Fronteira Ampla e na Borda Amazônica (figura 14 y 15), por nível hierárquico, constata-se que as taxas de urbanização dos níveis intermediários concentrado e disperso são mais ou menos constantes para os dois subespaços nos anos dos censos populacionais de 1980, 1991 e 2000. Somente no último ano é que seu ritmo de crescimento será pronunciado, alcançando 39\%, na Borda Amazônica. Como há uma manutenção do ritmo de urbanização no nível Superior nos anos 2000 e 2010 e uma quebra do ritmo de urbanização no nível Inferior em 2010, nesse subespaço, presume-se que o processo de re-hieraquização da rede urbana brasileira avança, sobretudo, em função da ampliação da base urbana nas áreas de fronteira. 


\section{Conclusóes}

Um dado histórico frequentemente esquecido sobre a formação socioespacial da América Latina é que as suas estruturas agrárias e agrícolas influenciaram diretamente no padrão de urbanização. A análise das mudanças nas hierarquias urbanas brasileiras, ao levar em conta o caráter reflexo da urbanização no contexto do subdesenvolvimento, chama a atenção para essa particularidade. E o surgimento de arranjos urbanos intermediários matizam tal caráter no que chamamos de novas determinações urbano-regionais, ilustradas pelas mudanças nas áreas não metropolitanas situadas na Fronteira Ampla e na Amazônia Oriental do Brasil, onde uma série de investimentos influíram na expansão da fronteira produtiva e na intensificação da urbanização.

Quanto ao objeto de análise, tratamos os arranjos urbanos intermediários, ao mesmo tempo, como um recorte de certos subespaços interregionais ou de subespaços específicos numa mesma regiáo e um ajuntamento de lugares dispersos que criam interconexóes, para que um determinado território realize seu movimento de modernidade seletivamente ou, em menor grau, contiguamente. Consideramos que esses arranjos não estão livres do monopólio socioeconômico exercido pelas áreas metropolitanas, que subordinam os espaços subnacionais em consonância com o processo reflexo de urbanização, fruto de interesses distantes. Comprovao a experiência comum que parte dos países latino-americanos divide em relaçáo aos impactos das políticas neoliberais e das perspectivas de investimentos previstas na IIRSA (Iniciativa para a Integração da Infraestrutura Regional Sul-Americana), surgida em 2000, para a modernizaçáo da infraestrutura física da região via megaprojetos de investimento.

Finalmente, podemos concluir que as cidades não pararam de crescer no período neoliberal. Foram as formas de articulação entre cidades que mudaram, especialmente quando considerado o acúmulo de obstáculos ao desenvolvimento urbanoregional no Brasil. A "guerra fiscal” levou à competição entre governos regionais e alimentou a "guerra de lugares", criando valor diferencial aos empreendimentos capitalistas no espaço, conforme o poder de uso e controle desses empreendimentos sobre os recursos naturais, sociais e econômicos do território. Nesse sentido, a configuração (estática) da rede urbana torna-se menos importante que os processos de hierarquização (dinâmico) no atual estágio do capitalismo, podendo gerar, inclusive, uma superierarquização nas redes urbanas dos países latino-americanos, resultante de profundadas assimetrias incorridas na urbanização reflexa. 


\section{Referências bibliográficas}

Becker, B. (1985). Fronteira e urbanização repensadas. Revista Brasileira de Geografia, 47(3/4), 357-371.

Becker, B. (2013). A urbe amazônica: a floresta e a cidade. Rio de Janeiro: Garamond.

Banco Nacional de Desenvolvimento Econômico e Social (BNDES). (2011). Visão do Desenvolvimento. Informativo da Área de Pesquisas Econômicas (APE), no 92. http:// www.bndes.gov.br/SiteBNDES/export/sites/default/bndes_pt/Galerias/Arquivos/ conhecimento/visao/Visao_92.pdf

Boletim de Investimentos Chineses no Brasil, 2012-2013 (2014). Conselho Empresarial Brasil-China. Rio de Janeiro. http://www.cebc.org.br/sites/default/files/boletim_de_ investimentos_-_final_0.pdf

Brandt, C.T. (2010). A criação de municípios após a Constituição de 1988. Revista de Informação Legislativa, 47(187), 59-75.

Brasil (2007). Plano Nacional de Logística e Transportes - PNLT. Relatório Executivo. Brasília: Ministério dos Transportes. http://www.transportes.gov.br/images/Relatorio_ Executivo_2007.pdf

Brasil (2015). Presidência da República. Casa Civil. Decreto no 8.447, de 6 de maio de 2015. Dispóe sobre o Plano de Desenvolvimento Agropecuário do Matopiba e a criação de seu comitê gestor. Brasília.

Brasil/MAPA - Ministério da Agricultura, Pecuária e Abastecimento. (2013). Projeçóes do Agronegócio: Brasil 2012/2013 a 2022/2023. Assessoria de Gestão Estratégica. Brasília: Mapa/ACS.

Cano, W. (2002). Ensaios sobre a formação econômica regional do Brasil. Campinas, SP: Universidade Estadual de Campinas (Unicamp).

Jordan, R. \& Simioni, D. (Comps.). (1998). Ciudades intermedias en América Latina y el Caribe: propuesta para la gestión urbana (LC/L.I I I7). Santiago, Chile: Comisión Económica para América Latina y el Caribe (CEPAL). http://repositorio.cepal.org/bitstream/ handle/11362/31024/1/S9800066_es.pdf

Confederação da Agricultura e Pecuária do Brasil (cNA). (2013). Agronegócio: balanço 2013, perspectivas 2014. Brasília, DF. http://www.canaldoprodutor.com.br/sites/default/files/ balanco_CNA_2013_web.pdf

Instituto Brasileiro de Geografia e Estatística (IBGE). (2010). Censo Demográfico. Rio de Janeiro. http://www.censo2010.ibge.gov.br/

Instituto de Pesquisa Econômica Aplicada (IPEA). (2001). Caracterização e tendências da rede urbana do Brasil: desenvolvimento regional e estruturação da rede urbana (Vols. 1-6). Redes Urbanas Regionais: Norte, Nordeste e Centro-Oeste (Vol. 4). Brasília, DF: IPEA, IBGE, UNICAMP.IE/NESUR

Informe China-Brasil Update (2015). Conselho Empresarial Brasil-China. Rio de Janeiro. http://www.cebc.org.br/pt-br/publicacoes-e-informes/china-brasil-update/chinabrazil-update-edicao-11

Lobato Corrêa, R. (2006). Estudos sobre a rede urbana. Rio de Janeiro: Bertrand Brasil.

Lobato Corrêa, R. (2011). Trajetórias geográficas. Rio de Janeiro: Bertrand Brasil. 
Moura, R. (2009). Arranjos urbano-regionais no Brasil: uma análise com foco em Curitiba. Tese (Doutorado), Programa de Pós-Graduação em Geografia da Universidade Federal do Paraná (UFPR), Curitiba, PR.

Santos, M. (2008a). Da totalidade do lugar (1a ed., $1^{\text {a }}$ reimpr.). São Paulo: Editora da Universidade de São Paulo (Edusp).

Santos, M. (2008b). Manual de geografia urbana. São Paulo: Editora da Universidade de São Paulo (Edusp).

Santos, M. (2009). A urbanização brasileira (5a ed., 2a reimpr.). São Paulo: Editora da Universidade de São Paulo (Edusp).

Valec (2016). Mapa das Ferrovias. Valec Engenharia, Construçôes e Ferrovias S.A. Brasília, DF. http://www.valec.gov.br/acoes_programas/Downloads/ MapaFerroviasValec_07-03-2016.pdf

Vieira, A.B., Nunes, M. \& Guimarães, R.B. (2010). Desigualdade e exclusão em cidades médias brasileiras. Em E. Melazzo \& R.B. Guimarães (Org.), Exclusão social em cidades brasileiras: um desafio para as políticas públicas (pp. 59-71). São Paulo: Editora da Universidade de São Paulo (Edusp). 